\title{
化膿性頸椎炎の治療成樍
}

\author{
長崎労災病院整形外科 \\ 小西宏 昭・原真一郎 \\ 佐世保市立総合病院 \\ 吉 良 秀 秋 \\ 国立川棚病院整形外科 \\ 新 村 哲 也
}

\section{Clinical Results in Pyogenic Cervical Osteomyelitis}

by

\author{
Hiroaki Konishi and Shinichirou Hara \\ Department of Orthopaedic Surgery, Nagasaki Rosai Hospital \\ Hideaki Kira \\ Department of Orthopaedic Surgery, Sasebo Sougou Hospital \\ Tetsuya Niimura \\ Department of Orthopaedic Surgery, Kawatana National Hospital
}

\begin{abstract}
11 cases with pyogenic cervical osteomyelitis were followed. 9 cases were operated on and 2 cases were treated by nonoperative methods. Clinical results were good in 9 cases. Two cases had sever neurological problems at follow up inspite of receiving emergency surgery.

These cases had initially severe paralysis (Frankel A or B). Age, sex, DM and the duration from initial symptoms to operation had no influence on clinical results.

We believe that initial neurological severity influenced final results.
\end{abstract}

Key words : pyogenic cervical osteomyelitis (化膿性项椎炎), clinical results (臨床成績), vertebral osteomyelitis (化膿性春椎炎)

\section{はじめに}

化膿性脊椎炎のなかで, 化朖性项椎炎は麻禆程度や その発生頻度が高く，他の部位の脊椎炎と比較してそ の治療成績は少る. 今回複数施設の化脹性頸椎炎を調 查し, その特徵と治療成績に関連する因子について検 討を加えたので報告する.

\section{対象及び方法}

1987 年より, 長崎労災病院, 佐世保市立総合病院, 国立川棚病院の 3 施設で治療を行った 11 例を対象之
した。初診時年齢は 39 歳より 73 歳平均 64 歳. 性別 は, 男性 8 例, 女性 3 例であった，以上の症例の発病 様式 (急性, 亜急性, 遷延), 麻㾝の程度 (Frankel 分類), 後咽頭腔幅ないし気管後腔, 䍜患高位, 治療 法, 起炎菌, 誘因, 基礎疾患, 手術の時期, 治療成績 を調查した。

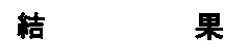

発症形式は，急性型 6 例 (55\%), 亜急性型 4 例 (36\%)，要延型 1 例（9\%) であった，麻搷の程度は $\mathrm{A}: 1$ 例, B : 1 例, C : 4 例, D : 2 例, $\mathrm{E}: 3$ 例で 
あった，後咽頭腔幅ないし気管後腔は $12 \mathrm{~mm}$ から $27 \mathrm{~mm}$ 平均 $19.4 \mathrm{~mm}$ と著しく拡大していた。櫂患高 位は, 2 椎体䍜患では $\mathrm{C} 4 / 5: 5$ 例, C $5 / 6: 2$ 例, C6 $77: 2$ 例, 3 椎体䍜患で $\mathrm{C} 4 / 5 / 6: 1$ 例, C $5 / 6 / 7: 1$ 例であった，治療法は麻痻の軽度な 2 例が抗生剂のみ による保存的治㙩を，9例が前方掻爬固定術を行った. そのうち 1 例は择爬術を行い 2 期的に固定術を行った。 起炎菌はSt. aureus が 4 例, E, coli が 1 例, Enterobacter cloacae が 1 例であり 5 例は不明であっ

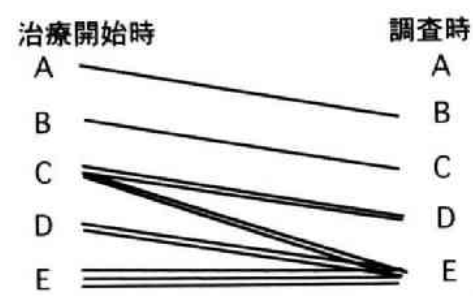

Frankel 分類

図 1 治漂成績

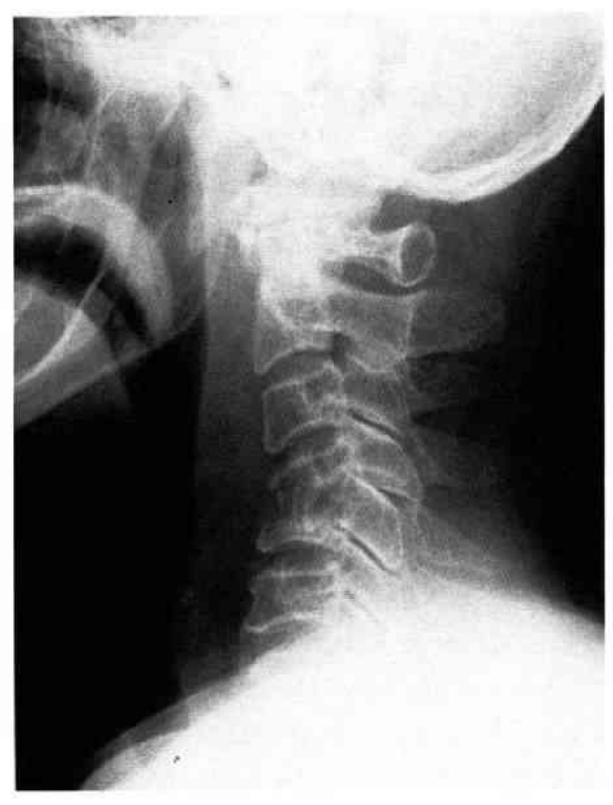

術前
た. 2 例は敗血症となっていた。明らかな誘因が存在 した例は 2 例であり，1例は钼部への頻回の注射，1 例は腰椎の硬膜外チュープの感染後敗血症となりその 後化膿性钼椎炎となった。基礎疾患は糖尿病が 6 例 (54.5\%) と最も多く, 蒾槽膿漏 1 例, 慢性気管支炎 1 例であった。手術例での発症より手術までの期間は 3 日より 54 日で平均 23 日であった。最終治療成䋶 (図 1) は, 麻㾝のあった 8 例中 2 例は, Frankel B およびCにとどまり不良であった。他は 1 段階以上 の改善を示し, Frankel Dないし E で良好な治療成 績であった，予後不良の 2 例は麻痷発生後それぞれ 2 日，3 日と可及的早期に治療開始したにあ関わらず感 染症は治瘁したものの神経学的な改善は満足できるも のではなかった.

\section{症}

\section{例}

症例 $1 （$ 図 2，3）：72 歳女性, 糖尿病, 腰痛に 対して腰椎部硬膜外チュービングを施行され，2 日後 より発熱, 硬膜外膿演で緊急手術, その後上肢麻掉出

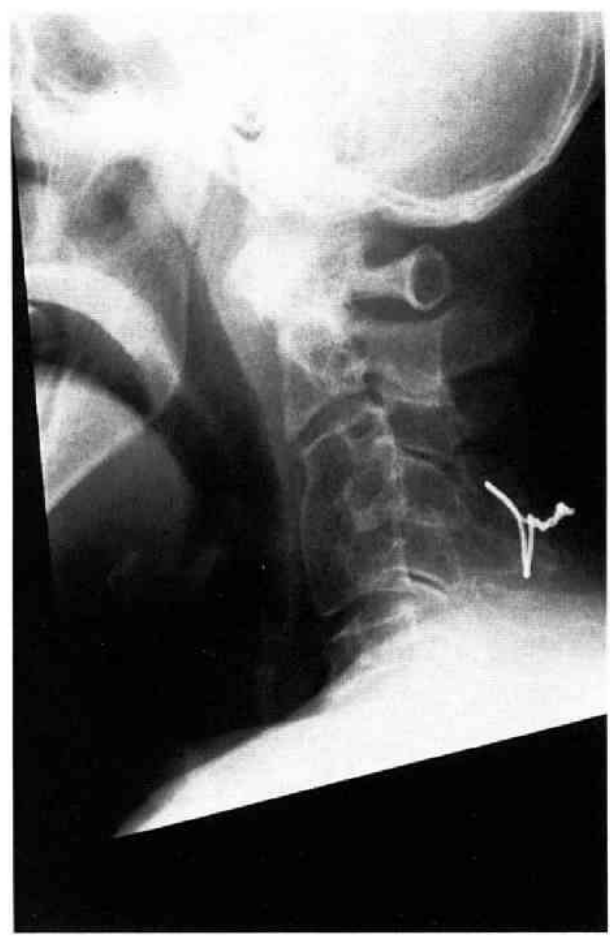

術後

図 2 症例 1. 前方固定術により麻痷はFrankel B からDへと改善した。 


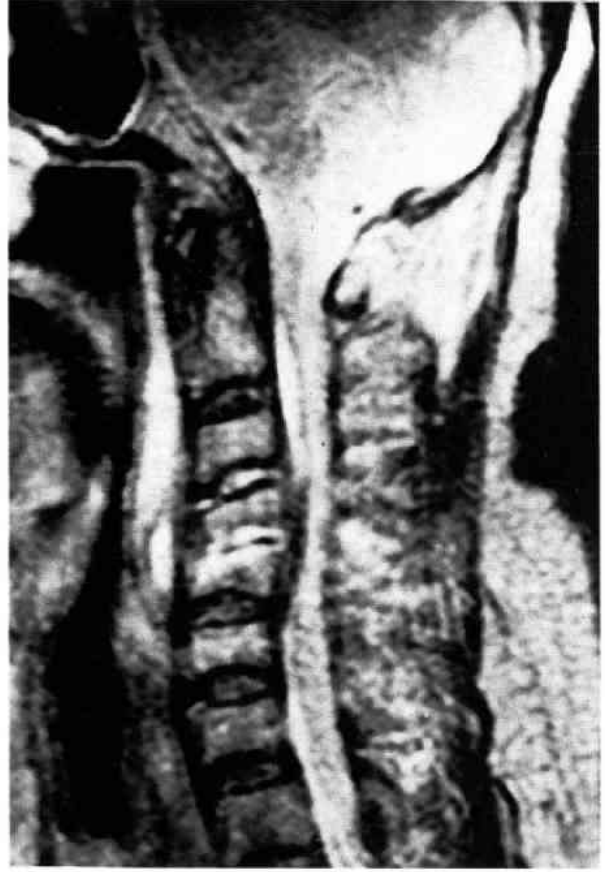

術前 MRI

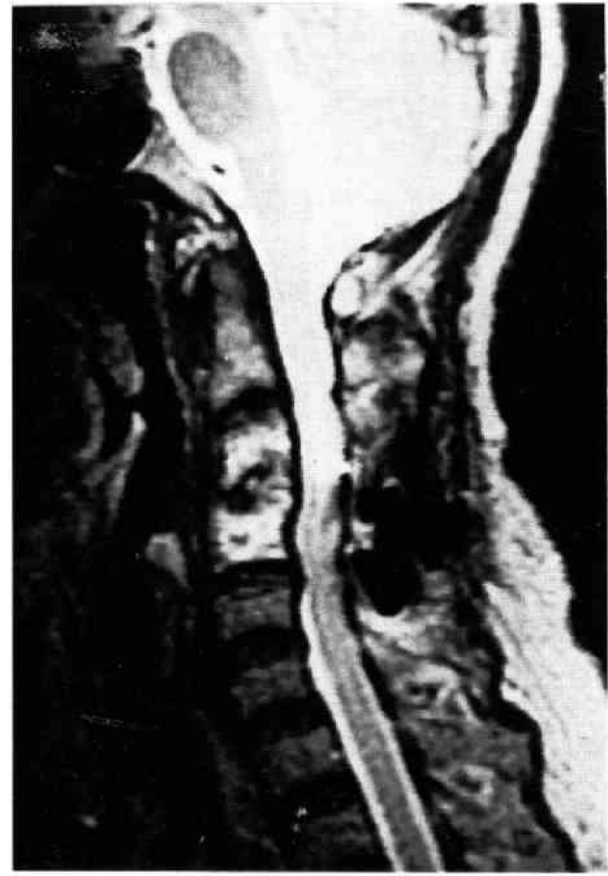

術後 MRI

図 3 症例 1 ，の術前術後の MRI を示す.

辅内に輝度変化が残存している.

現し, Frankel B の状態となる. 前方择爬固定術と梀 突起間 wiring を行い Frankel D へ改善, 起炎菌は St. aureusであった.

\section{症例 2（図 3，4）：68 歳男性 糖尿病}

钼椎部に数度の局所注射を受ける. 発熱之頌部痛が 出現し, 翌日より四肢不全麻㹸 (Frankel B) で受㟝 し直ちに前方掻爬固定術を施行した。しかし, 現在 Frankel C で良好な改善とは言えない.

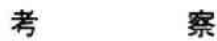

化膿性頸椎炎の診断は, 病期や䍜患部位によっては 必ずしも容易ではない，C5/6 が最も多いが， C6/7 あ 決して少なくなく”戦純レントゲン像で盲点になりや すい，その場合後咽頭腔幅を観察することが重要とな る. 自験例でも 2 例では初診時のレントゲンでの見逃 しがあった。

次に起炎菌は, 化膿性奉椎炎全般では, 確定診断以 前から投与されている抗生物質により不明な場合が多 いとされている，自験例は6 例 $54.5 \%$ て明らかとなっ
た.そしてその中の 4 例が, St. aureusであり諸家の 報告”と同様であった，頸椎以外の化膿性春椎炎に比 較して起炎菌の判明率が高いのは手術を行う率が高く 十分な標本が得られることも理由の 1 つであろう。

化膿性奉椎炎は，一般に保存的治療の適応が多いが, 化㜊性頸椎炎では，麻㽻の合併頻度が高いこと，予後 不良例が多いこともあって観血的治療を選択される場 合が多い，麻疩の発生頻度は，斉鹿ら ${ }^{57} \cdot$ は $53 \%$, Eismont $^{33}$ は $82 \%$ であり自験例では $73 \%$ であった. 治療成績は，最近の報告は良好であるものが多いが， 治療時の麻㽻の程度と治療成績については明らかになっ ていない, 斉鹿ら ${ }^{5}$ の JOA score 0 点の症例は中等 度の神経障害が残存している。また，浅尾ら 23 の Frankel B の症例は C への改善にとどまっている. 我々の 2 例であ神経学的改善は不十分であった。斉鹿 ら ${ }^{53}$ は Eismont ${ }^{3)}$ の治潦成績が不良であることを麻 禆発現から手術までの時間経過が長かったことを指摘 しているが, 自験例では麻㾝重症例は早期の手術にも 関わらず予後は不良であり，麻疾の重症度が予後を決 


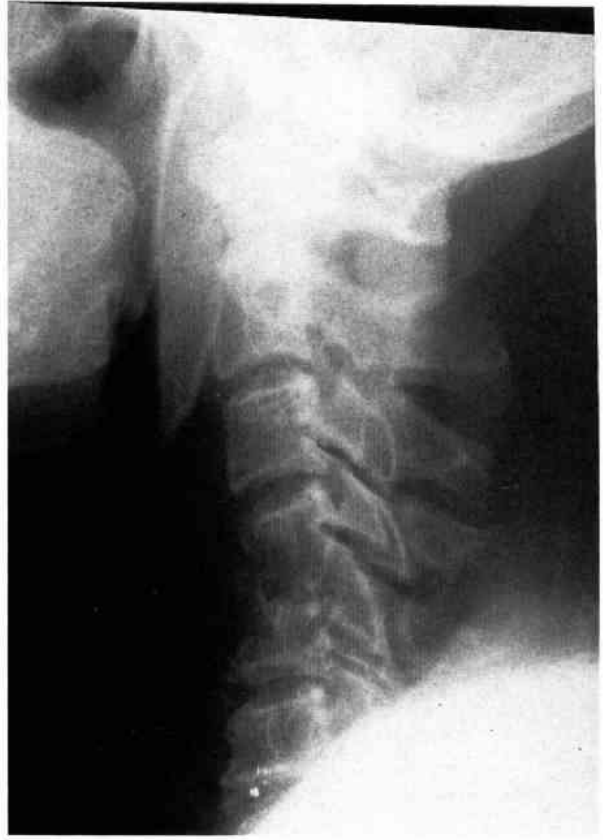

術前

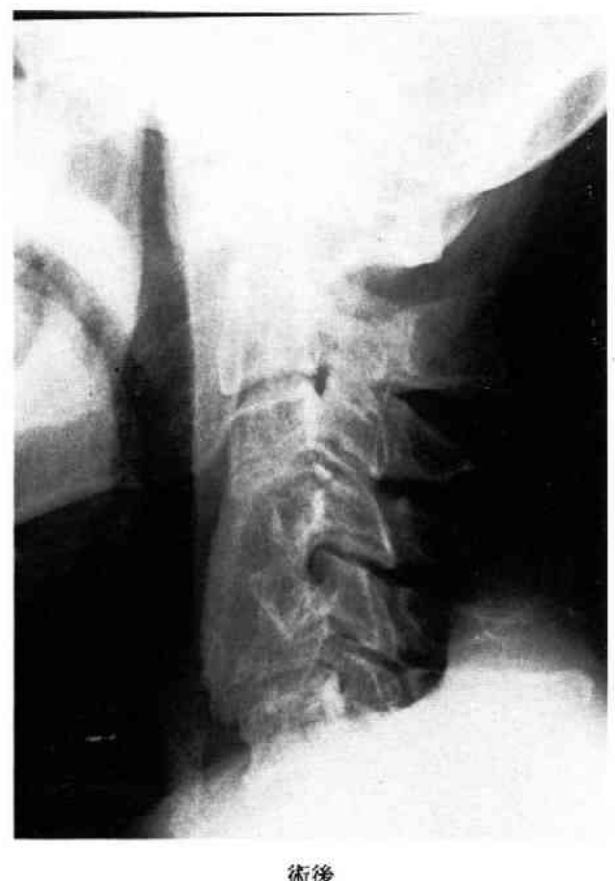

術後

図4 症例 2,の術前後のレントゲン像. 良好なアライメントになっているが麻䄍はBから Cへの改善に留まっている。

定する大きな因子であると推察できた.

観血的治療法としては前方除圧固定術が一般的であ り，それ以外の治療法は，文献的にも数例にすきない． 病紧掻爬と破壊された支持機構の再建という観点から 最む適切な方法であろう。

発症の原因と基礎疾患については, とりわけ糖尿病 が問題となる，化膿性会椎炎全体としては $5 \%$ から $50 \%$ まで様々な報告がある゙が，自験例の $54.5 \%$ は極 めて多いといえる，斎鹿ら ${ }^{51}$ は星状神経節プロックに よる感染が多いことを指摘し，多田ら ${ }^{6)}$ は 5 例中 2 例 が椎間板造影後の感染であったことを報告しているか， 自験例でも 2 例に医原性といえる例が存在し，内 1 例 は起炎菌としてMRSA を検出した，星状神経節プロッ クはもとより，局所注射や硬膜外チュービングなどに おいてす十分な清潔操作が望まれる.

結語

1. 化膿性頸椎炎の 11 例について検討した.

2. 特徵として, 病型では遷延型が少なく, 高位で
は中下位頸椎が多く，特に下位钼椎での単純レントゲ ン像の読影は慎重を要する。

3. 治療法は，主に前方掻爬固定術を行い2 例を除 いてほぼ満足できる治療成績であった。

4. 起炎菌の検出率は $54.5 \%$ ，糖尿病の合併率は $54.5 \%$ ，医原性といえる例は 2 例であった.

5。予後不良例は, 初診時からの高度麻㽻例であり， 麻狟の重症度が予後に関与すると思われた。

\section{参考 文 献}

1）会田育男, 林浩一郎, 和田野安良 : 化服性春椎炎の䧢 床的検討. 整形外科 44, 905-911，1993.

2）浅尾恒德，上田恵亮，村尾 哲他：手術治療を行った 頸椎化膿性脊椎炎の㭘討。整形外科と災害外科 43 ： $712-715,1994$.

3) Eismont, F. J., Bohlman, H. H., Soni, P. L. et al. Pyogenia and fungal vertebral osteomyelitis with paralysis. : J. Bone Joint Surg. 65-A : 19-29. 1983.

4）大平民生 : 頸颈椎部化朖性脊椎炎の 4 例. 整形外科 39. $883-889,1988$.

5）斎鹿 稳，河合伸也：頚椎化膿性春椎炎の郜床的特徽 


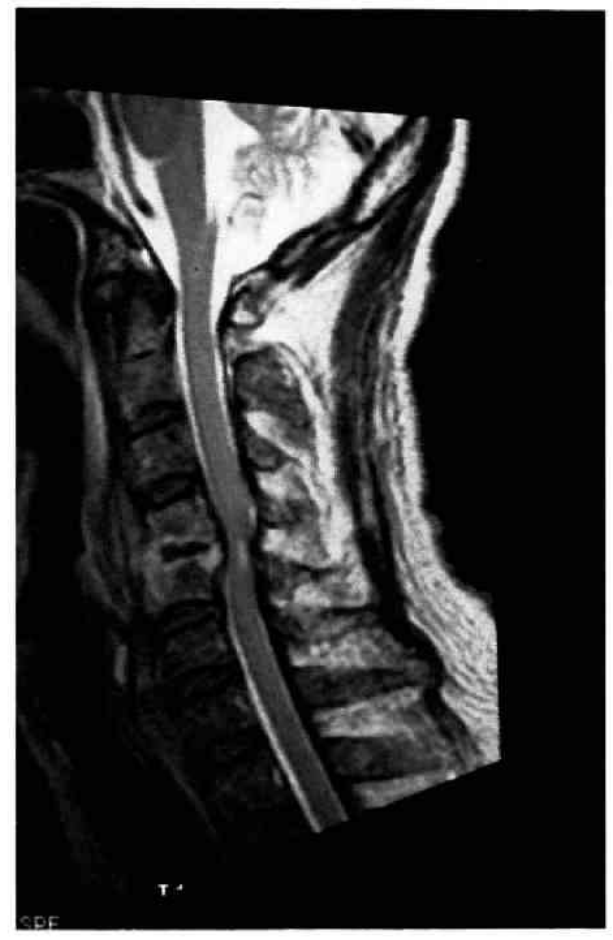

術前 MRI

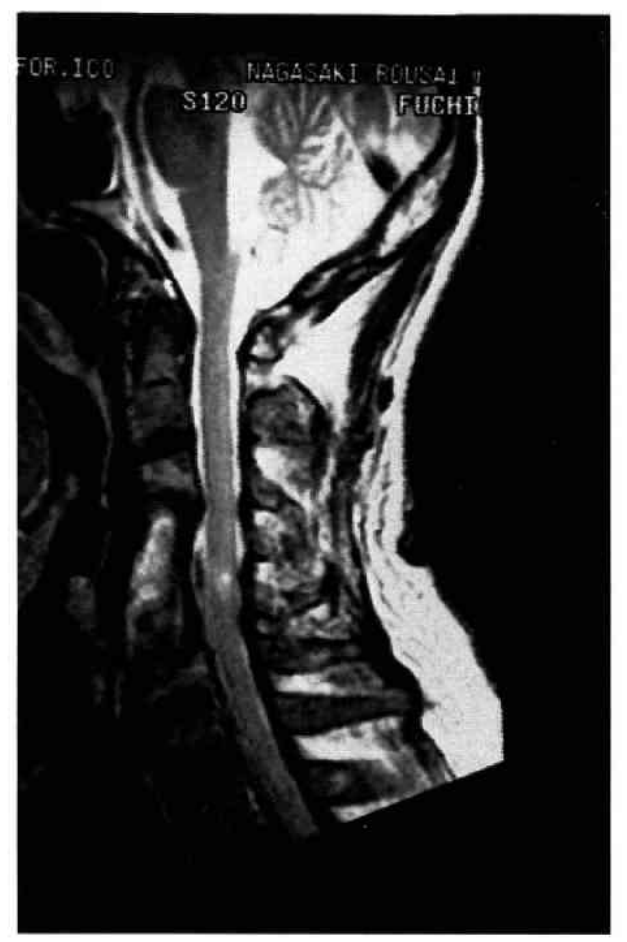

術後 MRI

図 5 症例 2 ，の術前後の MRI を示す。十分な除圧であるが麻疸の改善は不良であった。

からみた治癔. MB Orthop. 9. 37-41，1996.

6）多田健治, 宮崎和躬, 松田康孝他: 化脸性春椎炎によ る脊随麻㾴の治療. 整形外科 $41.1357-1363 ， 1990$.
7）若狭雅彦, 馬場逸志, 石田了久他: 頸椎化晨性春椎炎 の治旗経験. 整形外科 41. 1021-1028. 1990. 